\title{
The Analysis of the Current Situation and Prospects for Tourism Real Estate in China
}

\author{
LIU Lijun ${ }^{1, a}$, WANG Jing ${ }^{2}$, HE Yuanyuan ${ }^{3}$ \\ Economic and Trade Institute, Shijiazhuang university of economics, P.R. China, 050031 \\ Shijiazhuang University of economics, P.R. China, 050031 \\ Shijiazhuang institute of railway technology ,P.R. China, 050000 \\ a E-mail blue800410@126.com
}

Keywords: Real-estate for tourism. Development. Real-estate. Environment.

\begin{abstract}
Real-estate for tourism is an extension of timeshare in China market. The real estate and tourism initiative created this new format in terms of economic growth an environmental change. Real-estate for tourism in China has undergone more than two decades of development, in the great achievements made at the same time exposed a lot of problems: Which one is the focus of real-estate for tourism between tourism in and real estate? Is it a simple superposition of the tourism and real estate? What is the difference between this new form of real estate and other property? Taking the advantage of the combinations of theory and practice, quality study and quantity analysis, data collection and field research, this paper gives answers to these questions through analysis of the development of real-estate for tourism in China market.
\end{abstract}

\section{Introduction}

The early nineteen eighties, tourism industry began to develop in China, especially since the end of last century, the tourism industry as "sunrise industry" by the national advocate energetically, become the new period in our country and a new growth point of national economy. And people's life is closely related to the real estate industry, the introduction of housing system reform in our country, also got unprecedented development, become the pillar of the national economy. The tourism industry and the real estate industry is the tertiary industry with high added value, a strong association between the industry, tourism real estate with the development of tourism industry has generated and development.

At present the domestic research is generally believed that the tourism real estate originated in medieval Europe, France 1964 the Alps area, in the form of sales Resort Villa by " time ", this form was introduced to Switzerland and other European countries, gradually in the nineteen seventies, it was introduced in the United States, later, Americans joined the "timeshare " concept in the sales, and developed into the current popularity in Europe and America " vacation exchange system ". In Europe and the United States did not travel real estate this fixed vocabulary, only single word " Tour " and " Real estate " and " Timeshare ". Timeshare in China market has been extended to the tourism real estate, with economic growth and the impact of environmental changes, real estate and tourism initiative combined to produce a new format. A review of China real estate for tourism, begin at the tourism city such as Shenzhen, Shanghai and so on, to the second, three line tourism cities gradually. China's booming tourism development provides enormous space for tourism real estate development, and also brings huge market demand, on one hand the city's tourism real estate show a luxurious lifestyle, on the other hand, the tourism real estate in scenic town which has beautiful natural scenery is the public favor.

\section{The Generation and Development of China's Tourism Real Estate}

Tourism real estate is accompanied by China's modern tourism development, and the national tourism policy and the level of economic development are inextricably linked, China's tourism 
development has experienced from the sightseeing to the leisure of a process, tourism real estate has approximately experienced three development stages.

First of all, in 1978 the National Tourism puts forward on working conference tourism work from " political reception " change to " economic management ", marks the formal beginning of modern tourism industry, tourism is not only a formal reception function, enter the market to manage, build a batch of modern hotel became the urgent need. In order to change the Tourist Hotel behind the international tourism demand situation, introduce foreign capital in great quantities, sole proprietorship, joint venture, cooperative Tourist Hotel, is now the mainstream of the development of tourism real estate, strictly speaking, this is not in the true sense of the tourism real estate.

In ninety time, along with the State Council in 199212 National Tourism Resort examination and after more than 100 Provincial Tourism Resort built in 1996 and the "holiday tourism year" begin, vacation tourism is becoming tourism characteristics. The Chinese tourism real estate development has entered a new stage, in the real estate overall warming background, investment is large, covers an area of large scale, regional economic effect of theme park and resort development and construction to become regional tourism hot real estate development, tourism real estate category from the hotel to recreational facilities, tourism shopping, holiday villas and other diversified coexist in the development situation, such as Shenzhen, Soughing, Hangzhou overseas Chinese town.

The third stage is to enter after twenty-first Century, as the national economy increase, and leisure tourism has gradually rise, the National Tourism Bureau and put forward to promote the domestic tourism and the "national plan of leisure ". The emerging tourism power status and strong consumer groups, the real estate market for our tourism development to provide vast development space. According to the national tourism sector statistics, by the end of 2007, a total of Star Hotel 13583, up 832 from the previous year, an increase of 6.5\%; national statistics included in the range of travel agency a total of 18943, than last year increase 986. My overnight travel and tourism foreign exchange earnings were ranked fifth and seventh, established the Asian tourism superpower. Is expected to " eleven five " period tourism income average annual growth rate of 103 '0. By 2010, China's tourism revenue will reach 1226000000000 Yuan, with an average annual growth rate of about $10 \%$, equivalent to $7 \%$ of GDP. By 2020, China will become the world's largest tourist destination country and the fourth largest source of tourists, tourism revenue reached 2500000000000 yuan, an average annual growth rate of 7\%, the proportion of GDP is increased to about 8\%. 2010 and 2020 international tourists will increase to 1000000000 people and 1560000000 people, 1995 -- 2020 the average growth rate will reach $4.1 \%$. In the leisure and tourism developed rapidly under the situation, set leisure, entertainment, holiday, living in one of the major leisure resort community to become the new direction of development of tourism real estate, such as the Chengdu State-color Days Township, wild duck lake in Kunming, overseas Chinese town of Shanghai, Tianjin in Tambo new town etc...

\section{Problems of the Tourism Real Estate Development}

\section{The Price of the Tourism Land-use and Tourism Real Estate}

China online query statistics in recent years “commercial, tourism and entertainment “,we can get the form 3-1.

TABLE 1 IN RECENT YEARS, COMMERCIAL, TOURISM AND ENTERTAINMENT FOR THE PRICE

\begin{tabular}{cccccccccc}
\hline Year & $\mathbf{1 9 9 9}$ & $\mathbf{2 0 0 0}$ & $\mathbf{2 0 0 1}$ & $\mathbf{2 0 0 2}$ & $\mathbf{2 0 0 3}$ & $\mathbf{2 0 0 4}$ & $\mathbf{2 0 0 5}$ & $\mathbf{2 0 0 6}$ & $\mathbf{2 0 0 7}$ \\
\hline Premium & 100.0 & 100.4 & 101.2 & 107.0 & 104.9 & 110.4 & 107.9 & 106.4 & 113.0 \\
Housing price & 101.0 & 99.6 & 102.0 & 102.4 & 102.3 & 170.0 & 104.6 & 104.6 & 106.0 \\
\hline
\end{tabular}

Tourism real estate prices according to the regional tourist resources and somewhat difference, the rich tourism resources, tourism real estate prices higher, vice versa. For example, coastal tourism real estate in Sanya, Hainan 10000 Yuan per square meter, Shenzhen 40000 Yuan, Zhuhai 20000 yuan, Qingdao 30000 Yuan, other less well-known Island Sea hills Island, tourism real estate prices are low, 
seascape room is $6000-8000$ per square meter, all over the country property buyers according to their own needs and the purchase of capacity to choose.

Tourism real estate in China just started time of more than 20 years, development practice ahead of theory research, whether in management or in the system there are some problems.

\section{The Lack of Experience}

China's tourism real estate is originally from the introduction of foreign timeshare began, from individual participation in tourism real estate investment and consumption motivation to compare, both at home and abroad is not very big difference, its commercial value is the same. But from the tourism property classification, due to domestic developers and investors in the tourism real estate is also understood to the lack of a deeper understanding of tourism real estate, therefore, accurate positioning, promotion, business and management model design, there are still a lot of problems. Timeshare is a pure consumer products, because the domestic market is not mature, the social development has not been generally reach a certain level of consumption, timeshare concept in the country's development also needs for a long time, in our country at present in some areas of the timeshare due to the lack of credit and other problems caused some confusion. In addition, China's tourism real estate development and operation of inadequate understanding, lack of comprehensive understanding, how will the experiences of other countries the localization becomes tourism estate development concern. On some fundamental questions about the lack of systematic research, blind development will result in the waste of resources and destruction of environment, in the scenic resort built villa must consider scenic area overall aesthetic value, pay attention to natural landscape and human landscape in harmony.

\section{The Management Level}

Tourism real estate development heat caused our country real estate development boom, developers to jump on the bandwagon, management level is uneven, and the majority of tourism real estate development project to manage dispersedly, without taking into account the brand effect and the sustainable development benefit, existing in the development of myopia, some crudely made project will destroy the scenic resources, and even some tourism real estate business in the event went on sale after a stop on the investment in tourism projects, resulting in scenic resource destruction and idle. Due to the lack of market access and industry regulation, a bit of tourism real estate become developers "enclosure" in a form, resulting in a tourism real estate market confusion and depression.

Because the domestic some real estate developers eager, think tourism real estate is just as a second home, and not the common people residence, often on the quality of housing has ignored, resulting in the loss of investors, such as some of Hainan's Marina Resort, some in place for more than 3 years the home of all electrical appliances will appear moisture damage, property management irregularities, the poor quality of housing as an investment real estate for tourism people most worried about.

\section{Tourism Real Estate Market Information Asymmetry}

Any field problems of information asymmetry, but tourism real estate information asymmetry problem is particularly serious, but because of the information asymmetry problem exists in a large amount, resulting in China's tourism real estate in development a lot of problems. Tourism real estate is a posteriori commodity; only through the consumer personally consumption can experience the real estate quality, function and the corresponding services, and in the consumption process is finished, to their purchase of tourism real estate to make accurate judgment and evaluation, before buying the consumer is very difficult to collect related information. In addition, consumers purchase travel real estate, such as the hotel property, old-age leisure hotels, in addition to its own consumption, largely in pursuit of its investment value.

\section{The Relative Laws and Regulations}

Domestic at present about tourism real estate laws and regulations is almost a blank, there are many problems. 


\section{Summary}

Through the above theoretical discussion and case analysis, we get five tourism real estate development is the general principle, summed up is: in the scientific outlook on development guidance, independent innovation, establish a brand, resource integration, walk along dimensions to change development way, optimize management, finally to realize the sustainable development.

The scientific outlook on development guidance, " construction innovation country" has become a basic national policy, national government departments at all levels are strongly encouraged to enterprise innovation, and shouted " want beneficial result to innovation ", " promote the development of innovation " slogan. " Innovation" is the company formed a "competitive" start. Tourism real estate development itself is a just unfolding investment way, not many can learn from the successful experience, independent innovation ability is very important and necessary. In China's tourism development process has been exist blind copy, crudely made problem, investment real estate for tourism if also followed the tourism development all sorts of malpractices, is unable to realize sustainable development, even unable to recover the investment budget.

Tourism real estate is the rapid development of tourism product of modern tourism, is a significant embodiment. Large investment, comprehensive services, industry cluster is the tourist real estate must have the characteristics, tourism real estate development should not only consider the development of tourism, consideration should be given to estate value. In the dawn of the era of leisure tourism, tourism real estate as an important part of leisure tourism, leisure, vacation, health, entertainment in one of the large-scale management is the inevitable trend of future development.

The realization of sustainable development is the ultimate goal of tourism real estate development, sustainable development includes the sustainable development of tourism, sustainable development and operation of real estate, including the scenic resources protection of ecological environment, ongoing maintenance, realize the comprehensive coordinated sustainable development. Many of the domestic tourism real estate business in pursuit of profits, not taking the sustainable development as the ultimate goal, such as a Jiangxi local developers in the development of the theme park as a way to gather popularity, however in the real estate sales will develop to half of the theme park to stop, resulting in a large number of tourism land use of waste, to achieve sustainable development.

To sum up, the development of tourism real estate related content of carding and integration, and finally derives from the tourism real estate development countermeasure, has the theoretic and practical significance for guiding the dual, not only be helpful to the development of tourism real estate, also can enrich tourism estate theory study, from the perspective of Tourism real estate tourism development to provide draw lessons from.

\section{References}

[1] TanBingQing, MaChaoBo: Hebei energy consumption and economic growth of economic and technological analyzed. Cooperation, 2010,12(406):23-24.

[2] YuJiYong, TianJunShan: sail, HeZhanHang. Based on GM of energy consumption forecasting model of slope optimization [M]. Science, hydropower 2007,6 (25) : 115-117.

[3] WeiYiMing, LiangQiaoMei 2020. 2010 : regional energy for forecasting jaipur [R]. Beijing: China and college research report, 2006 forecast.

[4] Nelson, deng julong: GM $(1,1)[\mathrm{J}]$.j scope of system engineering theory and practice, 2000, (5) : 121-124.

[5] Fatai K, Oxley L, Scrimgeour F G. Modeling the causal relationship between energy and GDP in New Zealand, Australia, India, Indonesia, the Philippines and Thailand[J]. Mathematics and Computers in Simulation, 2010, 64: 431-445 